\title{
Impacts of Fertilization on Biologically Cycled P in Xylem Sap of Fagus sylvatica L. Revealed by Means of the Oxygen Isotope Ratio in Phosphate
}

\author{
Simon Hauenstein, Micha Nebel and Yvonne Oelmann* \\ Geoecology, Department of Geosciences, University of Tübingen, Tübingen, Germany
}

OPEN ACCESS

Edited by:

Jaane Krüger,

University of Education Freiburg,

Germany

Reviewed by:

Nicole Wellbrock,

Thuenen Instutitute of Forest Ecology,

Germany

Katelyn Elise Gray,

University of Delaware, United States

${ }^{*}$ Correspondence:

Yvonne Oelmann

yvonne.oelmann@uni-tuebingen.de

Specialty section:

This article was submitted to

Forest Soils,

a section of the journal

Frontiers in Forests and Global

Change

Received: 13 March 2020

Accepted: 24 August 2020

Published: 15 September 2020

Citation:

Hauenstein S, Nebel M and

Oelmann Y (2020) Impacts

of Fertilization on Biologically Cycled P

in Xylem Sap of Fagus sylvatica $L$.

Revealed by Means of the Oxygen

Isotope Ratio in Phosphate.

Front. For. Glob. Change 3:542738.

doi: 10.3389/ffgc. 2020.542738
Studies on the effect of high atmospheric $\mathrm{N}$ deposition report inconsistent results on forest productivity and $\mathrm{N}$ cycling which might be related to $\mathrm{P}$ availability in soil and subsequently affect tree $\mathrm{P}$ nutrition. We wanted to test the effects of (i) site i.e., a P-poor versus a $\mathrm{P}$-rich site and of (ii) fertilization $(\mathrm{N}, \mathrm{P}, \mathrm{N}+\mathrm{P})$ on inorganic $\mathrm{P}(\mathrm{Pi})$ and organic $\mathrm{P}$ (Po) concentrations as well as on biologically cycled phosphate (inferred from the $\mathrm{O}$ isotope signature after adding an ${ }^{18} \mathrm{O}$-enriched label) in xylem sap. We measured $\mathrm{Pi}$ and $\mathrm{Po}$ concentrations and the $\mathrm{O}$ isotope signature in phosphate $\left({ }^{18} \mathrm{O}_{P i}\right)$ in xylem sap of beech (Fagus sylvatica L.) trees two and 14 days after addition of ${ }^{18} \mathrm{O}$-enriched water to the organic layer in a full factorial fertilization experiment (control, $+\mathrm{N},+\mathrm{P},+\mathrm{NP}$ ) at two sites differing in $\mathrm{P}$ availability. Higher $\mathrm{P}$ concentrations in xylem sap at the $\mathrm{P}$-rich than at the P-poor site originated from accelerated biological $\mathrm{P}$ cycling indicated by incorporation of ${ }^{18} \mathrm{O}$ from the isotope label into phosphate in xylem sap shortly after labeling. At this site, $\delta^{18} \mathrm{O}_{W}$ values of xylem sap after label application remained close to background $\delta^{18} \mathrm{O}_{W}$ values of soil solution. We speculate that in contrast to $\mathrm{P}$ uptake, trees took up water from deeper (non- ${ }^{18} \mathrm{O}$-labeled) soil layers. At the P-poor site, the ${ }^{18} \mathrm{O}$ label was recovered both in xylem sap water and phosphate in xylem sap, the latter only after 14 days. These results imply that trees relied on the organic layer for $\mathrm{P}$ acquisition and water uptake. However, biological processes associated with an incorporation of ${ }^{18} \mathrm{O}$ from the label were slower at the P-poor than at the P-rich site. $\mathrm{P}$ addition $(\mathrm{P}, \mathrm{NP})$ increased $\mathrm{Pi}$ concentrations in xylem sap at the P-rich site. Based on $\delta^{18} \mathrm{O}_{P i}$ values in xylem sap, the additional $P$ originated both from the fertilizer and from accelerated biological P cycling in soil. We conclude that P-poor sites likely suffer more from climate change in case of an increased frequency of droughts because as opposed to P-rich sites both water and nutrient uptake will be affected.

Keywords: ${ }^{18} \mathrm{O}$ labeling, organic P mobilization, phosphorus nutrition, forest floor, soil, beech, phosphorus uptake 


\section{INTRODUCTION}

Phosphorus $(\mathrm{P})$ is an essential agent in a variety of vital processes like the build-up of DNA, RNA, and cell membranes, energy transfer via free nucleotides and carbon metabolism. Therefore, $\mathrm{P}$ is of paramount importance for plant growth and ecosystem performance (Marschner, 2002; Scheerer et al., 2018). Based on the decrease of foliar $\mathrm{P}$ concentrations during the last decades, $\mathrm{P}$ is suspected to limit the growth of trees (Fagus sylvatica L.; Pinus sylvestris L.) in forests and thus, forest productivity (Prietzel and Stetter, 2010; Jonard et al., 2015).

The drivers for P limitation in European forest ecosystems are mainly associated with anthropogenic activities. In particular, continuously high deposition of atmospheric $\mathrm{N}$ and increased $\mathrm{CO}_{2}$ concentrations due to climate change accelerate forest growth, consequently resulting in enhanced $\mathrm{P}$ demands by trees (Jonard et al., 2015; Talkner et al., 2015). However, the effect of increased $\mathrm{N}$ supply on forest growth reported so far are not consistent. Magill et al. (2004) found that forest growth was increased by $\mathrm{N}$ fertilization whereas $\mathrm{N}$ fertilization had no effect in several other studies (Nadelhoffer et al., 2004; Finzi, 2009; Lovett et al., 2013). Given an unbalanced N and $\mathrm{P}$ deposition together with the crucial role of phosphorus (P) in plant development, ecosystems are gradually moving from N to P limitation (Peñuelas and Sardans, 2012; Peñuelas et al., 2013). Gaudio et al. (2015) describe N limitation in forests to become crucial under climate scenarios where the turnover rate of organic matter is slow and $\mathrm{N}$ deposition continues to decrease. Consequently, other nutrients such as $\mathrm{P}$ could also become limiting in the future or are already limiting in nutrient-poor ecosystems (Jonard et al., 2012). For soils, Mo et al. (2015) found that $\mathrm{N}$ addition resulted in an overall decline in nutrient availability (except $\mathrm{N}$ ), which seemed to result from a decline in litter decomposition and increased soil acidification. Waldrop and Firestone (2004) reported that excess $\mathrm{N}$ reduced the production of enzymes involved in decomposition, particularly in lignin degradation. Thus, soil respiration and decomposition were reduced, while soil-organic matter accumulation in fertilized soils was increased (Pregitzer et al., 2007; Nave et al., 2009; Janssens et al., 2010). Therefore, positive growth responses of trees to $\mathrm{N}$ fertilization might be constrained by negative fertilization effects on decomposition rates. In addition, missing effects of $\mathrm{N}$ fertilization might be due to the fact that elements other than $\mathrm{N}$ limit forest growth.

Jonard et al. (2015) as well as Talkner et al. (2015) consider P as the upcoming limiting factor in nutrient poor forest ecosystems which yet has to be approved by $\mathrm{P}$ fertilization trials (Polglase et al., 1992; Clarholm, 1993). The effect of P fertilization likely depends on the type of nutrient acquisition in ecosystems. In "acquiring ecosystems," e.g., on young, nutrient-rich or just P-rich soils, $\mathrm{P}$ is mobilized from P-containing minerals in the soil and subsequently taken up by trees (Odum, 2014; Lang et al., 2016). In forests on old, highly weathered and/or P-poor soils, trees mainly rely on the mobilization from organically bound $\mathrm{P}$ in soil organic matter ("recycling ecosystems;" Hauenstein et al., 2018). Augusto et al. (2017) consider the parent material as the principal component controlling $\mathrm{P}$ availability in soils, beside the progression of pedogenesis, or climatic controls. This view is supported by Porder and Ramachandran (2012), who showed that parent material serves as a control of bioavailable $\mathrm{P}$ in soil. Findings of forest ecosystem adaptions toward a "recycling" system along decreasing nutrient supply from different parent materials are described by several authors (Lang et al., 2016, 2017; Hansson et al., 2020; Legout et al., 2020). In case of such P-poor soils, $\mathrm{P}$ fertilization increased forest growth/productivity (Blevins et al., 2006; Trichet et al., 2009; Turner and Lambert, 2015). This effect was likely driven by soil processes exemplary described by Mo et al. (2015) who found that the addition of $\mathrm{P}$ to soils containing very little available $\mathrm{P}$ resulted in a significant "priming" effect, which stimulated microbial activity and nutrient turnover of litter, whereas no effect of $\mathrm{P}$ addition was observed in soils containing sufficiently available P. This is in line with Bergkemper et al. (2016) who described a shift in bacterial communities which led to increased organic $\mathrm{P}$ acquisition on P-poor soils, whereas in P-rich soils inorganic P acquisition dominated. By contrast, several authors reported the downregulation of enzyme activity slowing down P mobilization from organic $\mathrm{P}$ after the addition of water soluble mineral $\mathrm{P}$ to soil irrespective of initial P availability in soil (DeForest et al., 2012; Marklein and Houlton, 2012; Shaw and DeForest, 2013). Whether these P fertilization effects on $\mathrm{P}$ availability in soil translate into tree P uptake via xylem sap has hardly been studied (Prietzel and Stetter, 2010). We expect that N and P fertilization effects on forest growth and nutrient availability in soil are reflected in $\mathrm{P}$ uptake by trees i.e., $P$ concentrations in xylem sap. In xylem sap, the addition of water-soluble mineral $\mathrm{P}$ to soil likely increases $\mathrm{Pi}$ concentrations by direct uptake of fertilizer $\mathrm{P}$ and by increased uptake from biologically cycled P originating from a stimulation of biological activity in soil.

To distinguish biological $\mathrm{P}$ mobilization processes from other processes, recent studies used the ratio of stable oxygen $(\mathrm{O})$ isotopes in phosphate $\left(\delta^{18} \mathrm{O}_{P i}\right)$ (Pistocchi et al., 2018; Hacker et al., 2019). This is possible because only biological processes involve an exchange between $\mathrm{O}$ atoms in phosphate and $\mathrm{O}$ atoms in ambient water (Blake et al., 2005), while no such exchange takes place during the dissolution of $\mathrm{P}$-containing minerals and the desorption of $\mathrm{H}_{2} \mathrm{PO}_{4}{ }^{-} / \mathrm{HPO}_{4}{ }^{2-}$ from charged surfaces (Liang and Blake, 2007). Particularly if the O isotope signature of ambient water is modified via isotope labeling by ${ }^{18} \mathrm{O}$-enriched- or ${ }^{18} \mathrm{O}$-depleted water, mobilization processes or distinct P sources can be identified (Hacker et al., 2019). Accordingly, an incorporation of $\mathrm{O}$ atoms from ${ }^{18} \mathrm{O}$-enriched ambient water into phosphate by biological activity in soil should be visible in $\delta^{18} \mathrm{O}_{P i}$ values of xylem sap once phosphate has been taken up by trees. Given the assumption that an acquiring ecosystem relies much less on nutrient release from organic matter via biological activity than a recycling ecosystem does, different contributions of biologically cycled phosphate i.e., different extents of ${ }^{18} \mathrm{O}$-enrichment, in xylem sap can be expected. Similarly, a stimulation of biological activity in the soil by $\mathrm{P}$ fertilization should be reflected in a greater contribution of biologically cycled phosphate particularly so in the recycling ecosystem. 
Our objectives were to test the effects of (i) site i.e., an acquiring versus a recycling ecosystem, and of (ii) fertilization $(\mathrm{N}$, $\mathrm{P}, \mathrm{N}+\mathrm{P}$ ) on $\mathrm{Pi}$ and Po concentrations as well as on biologically cycled phosphate (inferred from the $\mathrm{O}$ isotope signature after adding an ${ }^{18} \mathrm{O}$ label) in xylem sap.

\section{MATERIALS AND METHODS}

\section{Study Sites}

In the frame of the priority program SPP 1685 "Ecosystem Nutrition, Forest Strategies for limited Phosphorus Resources" (Lang et al., 2016), two temperate beech forest sites were selected for the purpose of this study. The site "Bad Brückenau" (BBR) is located in Bavaria, southeastern Germany in a midrange mountain area of the Rhön $\left(50^{\circ} 35^{\prime} \mathrm{N}, 9^{\circ} 92^{\prime} \mathrm{E}\right)$. The potential natural vegetation at the site BBR is Hordelymo-Fagetum (Lang et al., 2017). The forest stand comprises 99\% Fagus sylvatica L. and 1\% Acer pseudoplatanus L. Mean stand age of beech is 137 years with an average height of $26.8 \mathrm{~m}$, a mean (breast height) diameter of $36.8 \mathrm{~cm}$ and a tree density of 335 individuals per hectare. At this site, mull-like Moder forest floors on dystric skeletic Cambisols developed on alkaline igneous rocks/metamorphites (Haußmann and Lux, 1997). The order of organic soil horizons (IUSS WG WRB, 2015) was as follows, for LUE: Oi $(3 \mathrm{~cm})$ - Oe $(4 \mathrm{~cm})$ - Oa $(1 \mathrm{~cm})$ and for BBR: Oi $(3 \mathrm{~cm})$ - Oe $(3 \mathrm{~cm})$. Mean annual air temperature and the mean sum of annual precipitation are $5.8^{\circ} \mathrm{C}$ and $1031 \mathrm{~mm}$, respectively (Level II ICP-forest monitoring; Lorenz, 1995). At the site BBR yearly atmospheric $\mathrm{N}$ deposition was $13.8 \mathrm{~kg} \mathrm{~N} \mathrm{ha}^{-1}$ (measured between 2009 and 2012; personal communication Dietrich, H.-P., LWF-Bayern, Germany). For more detailed site characteristics see Lang et al. (2017). During the experimental course, soil temperature at a depth of $0.05 \mathrm{~m}$ was, on average, of $13.0 \pm$ standard deviation (SD) $0.4^{\circ} \mathrm{C}$. During this period of time, $26.6 \mathrm{~mm}$ throughfall were reported (personal communication Dr. Meesenburg, NW-FVA, Germany). The site "Lüss" (LUE) is located in Lower Saxony, northwestern Germany in the Lüneburg Heath $\left(52^{\circ} 83^{\prime} \mathrm{N}, 10^{\circ} 36^{\prime} \mathrm{E}\right)$. The potential natural vegetation at the site LUE is Luzulo-Fagetum (Lang et al., 2017). The forest stand comprises 91\% F. sylvatica and 9\% Quercus petrea (MATTUSCHKA) LieBl. Mean stand age of beech is 132 years with an average height of $27.3 \mathrm{~m}$, a mean (breast height) diameter of $27.5 \mathrm{~cm}$ and a tree density of 480 individuals per hectare. Organic layers and soil types are classified as a mor-like Moder forest floor on hyperdystric folic Cambisols developed from Pleistocene sands. The mean annual air temperature is $8^{\circ} \mathrm{C}$ and the annual sum of precipitation amounts to $779 \mathrm{~mm}$ (Level II ICP-forest monitoring; Lorenz, 1995). During the experimental course, the mean soil temperature mean at a depth of $0.06 \mathrm{~m}$ was $9.3 \pm \mathrm{SD} 0.1^{\circ} \mathrm{C}$ and $23.8 \mathrm{~mm}$ throughfall were observed (personal communication Mr. Dietrich, LWF-Bayern, Germany). At the site LUE, yearly atmospheric $\mathrm{N}$ deposition was $10 \mathrm{~kg} \mathrm{~N} \mathrm{ha}^{-1}$ (measured between 2009 and 2012; personal communication Dietrich, H.-P., LWF-Bayern, Germany). Sites were selected according to their bioavailability of $\mathrm{P}$, thus showing the ecosystem adaptions to different parent materials. We assume the influence of the climate conditions to be important but not fundamental for the development and adaptions of the forest ecosystems on these sites.

\section{Fertilization Experiment}

At both sites, a full-factorial fertilization experiment was established in April-May 2016. The experiment comprised a control and three fertilization treatments: $\mathrm{N}$ addition $(150 \mathrm{~kg} \mathrm{~N}$ $\mathrm{ha}^{-1}$ year $^{-1}$ as $\mathrm{NH}_{4} \mathrm{NO}_{3}$ ), $\mathrm{P}$ addition $\left(50 \mathrm{~kg} \mathrm{~N}^{-1}\right.$ year $^{-1}$ as $\mathrm{KH}_{2} \mathrm{PO}_{4}$ ), $\mathrm{N}+\mathrm{P}$ addition (combination of $\mathrm{N}$ and $\mathrm{P}$ addition). Control and treatment plots $(20 \mathrm{~m} \times 20 \mathrm{~m})$ were established in triplicates which were randomly distributed in the stands while keeping a minimum distance of $20 \mathrm{~m}$ between plots (Figure 1). Each plot contained at least two individuals of adult beech trees (F. sylvatica L.) with a diameter at breast height of $46.8 \pm \mathrm{SD}$ $3.65 \mathrm{~cm}$ at the site BBR and $48.8 \pm$ SD $5.81 \mathrm{~cm}$ at the site LUE and an approximate age of 120 years.

The control and the $\mathrm{N}$ addition treatments received $\mathrm{KCl}$ to account for the addition of $\mathrm{K}$ in P-containing treatments. The addition of $\mathrm{N}$ was split into five parts (30 $\mathrm{kg} \mathrm{N}^{-1}$ hach) in spring, summer, and autumn to account for the seasonal demand of trees and to reduce leaching losses. The addition of $\mathrm{P}$ took place once a year along with the $\mathrm{N}$ addition in spring. The fertilizer addition was carried out in dissolved form by means of garden sprayers. The experiment was conducted in July/August 2017. We acknowledge that by restricting the fertilization to $\mathrm{N}$ and $\mathrm{P}$, we did exclude the potential limitation of forest growth by elements other than $\mathrm{N}$ and $\mathrm{P}$ which was speculated by Jonard et al. (2012). We tried to simulate a conservative estimate of maximum $\mathrm{N}$ input for the next decade of atmospheric $\mathrm{N}$ deposition. Nevertheless, similar to many other forest fertilization experiments, our fertilization approach did not take into account direct interactions between the fertilizer and the canopy which would have occurred had we manipulated atmospheric deposition directly.

\section{Labeling by ${ }^{18} \mathrm{O}$-Enriched Water}

The isotope labeling took place June 19-21, 2017 at the site BBR and June 12-14, 2017 at the site LUE. We used an area of $10.8 \mathrm{~m}^{2}$ around each tree individual for the application of ${ }^{18} \mathrm{O}$ enriched water. This area was formed by two circles with an identical center in the middle of each tree with radii of 0.4 and $1.9 \mathrm{~m}$. We prepared ${ }^{18} \mathrm{O}$-enriched water by diluting tap water with ${ }^{18} \mathrm{O}$-enriched water $\left(>98\right.$ atom $\%{ }^{18} \mathrm{O}$, Hyox ${ }^{18} \mathrm{O}$, rotem, Arava, Israel) aiming at $\delta^{18} \mathrm{O}$ values of soil solution of around $+40 \%$. Assuming thermodynamic equilibrium fractionation (Chang and Blake, 2015), $\delta^{18} \mathrm{O}_{P i}$ values of $+61.7 \%$ would result (see calculations for realized $\delta^{18} \mathrm{O}_{W}$ values of soil solution in Supplementary Figure S1). We applied the ${ }^{18} \mathrm{O}$-enriched water using a syringe (100 ml, Vektenxi, amazon.de) that was composed of a $12 \mathrm{~cm}$ long needle with a closed tip and five outlet holes ( $1 \mathrm{~mm}$ diameter). We injected the ${ }^{18} \mathrm{O}$-enriched water into the $\mathrm{Oe}$ horizon and the injection depth was adapted to the site-specific forest floor structure in order to be centered in the Oe horizon. To assure homogeneous application of the label, the area was divided into eight subareas. 60 injections of $2.5 \mathrm{ml}$ water were allocated randomly to each subarea. In total, 1.21 of ${ }^{18} \mathrm{O}$-enriched water 

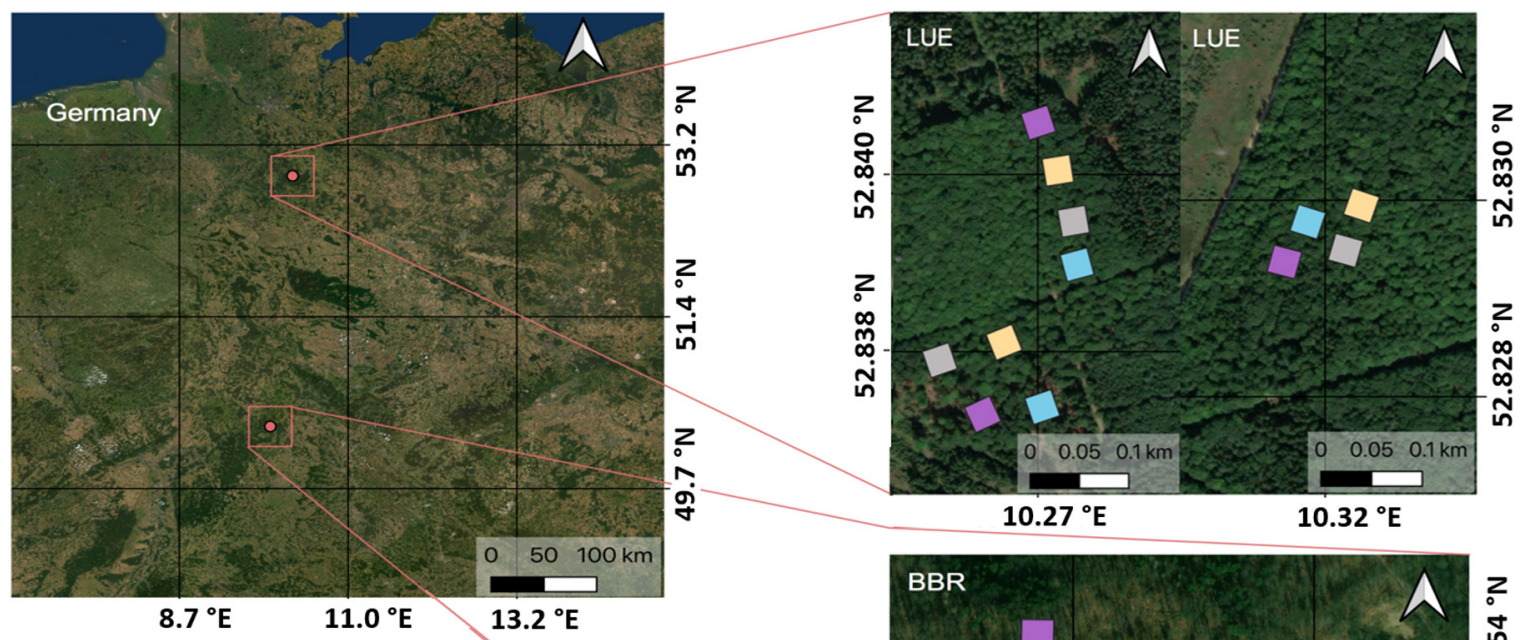

$8.7^{\circ} \mathrm{E} \quad 11.0^{\circ} \mathrm{E}-13.2^{\circ} \mathrm{E}$
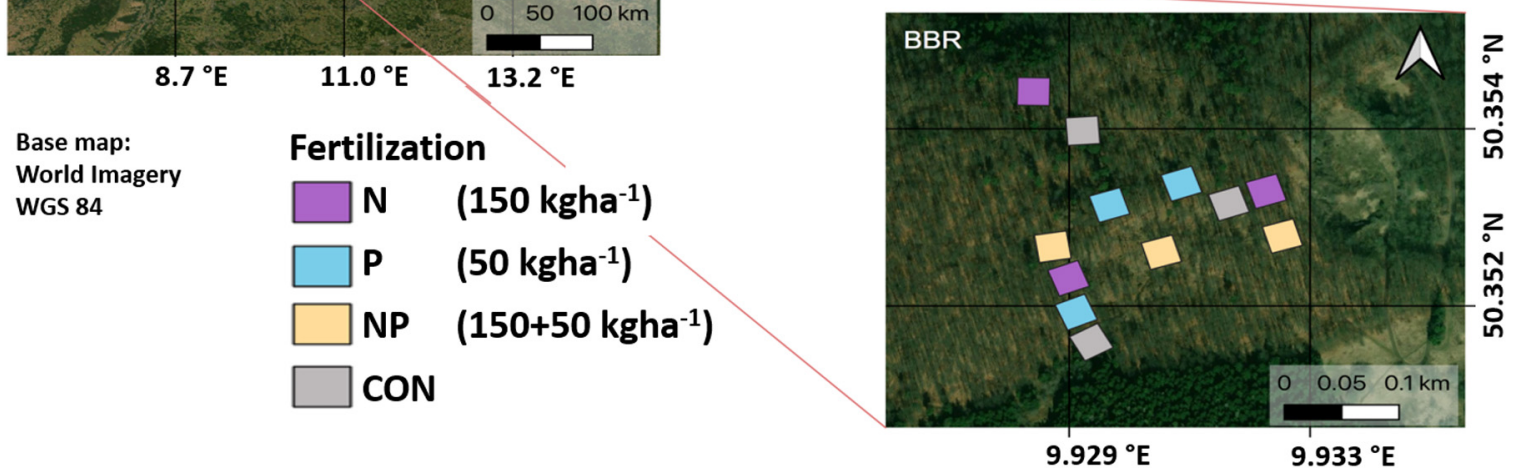

FIGURE 1 | Sitemap: experimental design of the fertilizer treatments (done in triplicate). The amount of fertilizer applied is given in brackets in $\mathrm{kg} \mathrm{ha}^{-1} \mathrm{year}^{-1}$ Nitrogen $(\mathrm{N})$ and phosphorus $(\mathrm{P})$ were applied as $\mathrm{NH}_{4} \mathrm{NO}_{3}$ and $\mathrm{KH}_{2} \mathrm{PO}_{4}$, respectively. Note that the control and $\mathrm{N}$ treatment received $\mathrm{KCl}$ to ease comparison with the $\mathrm{P}$ treatment which included the addition of K as well. Courtesy by Jaane Krüger; Source: Esri, Maxar, GeoEye, Earthstar Geographics, CNES/Airbus DS, USDA, USGS, Aerogrid, IGN, and the GIS User Community. To minimize visual distance of one triplicate of fertilized plots in LUE the coordinate system is adapted adequately, BBR = Bad Brückenau; LUE = Lüss.

was applied in the prescribed area around each tree individual and this equals $2.1 \%$ (BBR) and $1.7 \%$ (LUE) of the average soil water content in the organic layers. To check for resulting labeling of soil water, organic layer samples were taken and stored in gas-tight vials until isotope analysis.

\section{Xylem Sap Extraction and Sample Purification}

In total, we sampled 48 trees $(2$ sites $\times 4$ treatments $\times 2$ time steps $\times 6$ replicates). Two time steps were necessary to cover the potential duration until ${ }^{18} \mathrm{O}$-enriched phosphate originating from incorporation of ${ }^{18} \mathrm{O}$ from the water label in soil were taken up by the trees. To follow the uptake of ${ }^{18} \mathrm{O}$-enriched phosphate, we extracted xylem sap. To this end, branches (diameter of $0.8-2 \mathrm{~cm}$ ) were harvested by tree climbers from the middle canopy. Directly after harvesting, we removed $2 \mathrm{~cm}$ of bark and cambium to prevent contamination with phloem constituents and tightly pulled a PE hose over the twigs. The twigs were placed in the Scholander pressure bomb (Soilmoisture 3000 Series Plant Water Status Console). The pressure was applied as $\mathrm{N}_{2}$ gas (Grade 3). This procedure was repeated until a minimum amount of $30 \mathrm{ml}$ xylem sap was extracted. Directly after sampling the xylem sap was filtered through $1.2 \mu \mathrm{m}$ PET syringe filters
(CHROMAFIL Xtra PET-120/25, MACHEREY-NAGEL GmbH \& Co. KG, Düren, Germany). The samples were stored in a portable fridge at $4^{\circ} \mathrm{C}$. Aliquots were split for $\delta^{18} \mathrm{O}_{W}(1 \mathrm{ml})$ and $\delta^{18} \mathrm{O}_{P i}$ analyses.

Because some organic $\mathrm{P}$ compounds might be rapidly transformed into $\mathrm{Pi}$ in xylem sap, we processed xylem sap samples each day directly after returning from the field. We purified Pi following the protocol of Weiner et al. (2011) and added anion exchange resin membranes (VWR International $\mathrm{GmbH}$, Bruchsal, Germany) to the xylem sap samples. After $16 \mathrm{~h}$ of shaking, the membranes were removed, rinsed with $\mathrm{H}_{2} \mathrm{O}$ and eluated by $\mathrm{HNO}_{3}$. Eluates were again stored in a portable fridge at $4^{\circ} \mathrm{C}$ until preparation for isotope analysis in the laboratory. In the laboratory, the eluate was used for precipitation of silver phosphate as described by Weiner et al. (2011). In brief, the mineral precipitation and dissolution of ammonium phospho-molybdate was followed by mineral precipitation and dissolution of magnesium ammonium phosphate. After removal of cations and proof of the absence of chloride, silver phosphate was precipitated.

\section{Chemical Analyses}

Concentration of inorganic $\mathrm{P}(\mathrm{Pi})$ in xylem was determined spectrophotometrically with a continuous flow analyzer (CFA, 


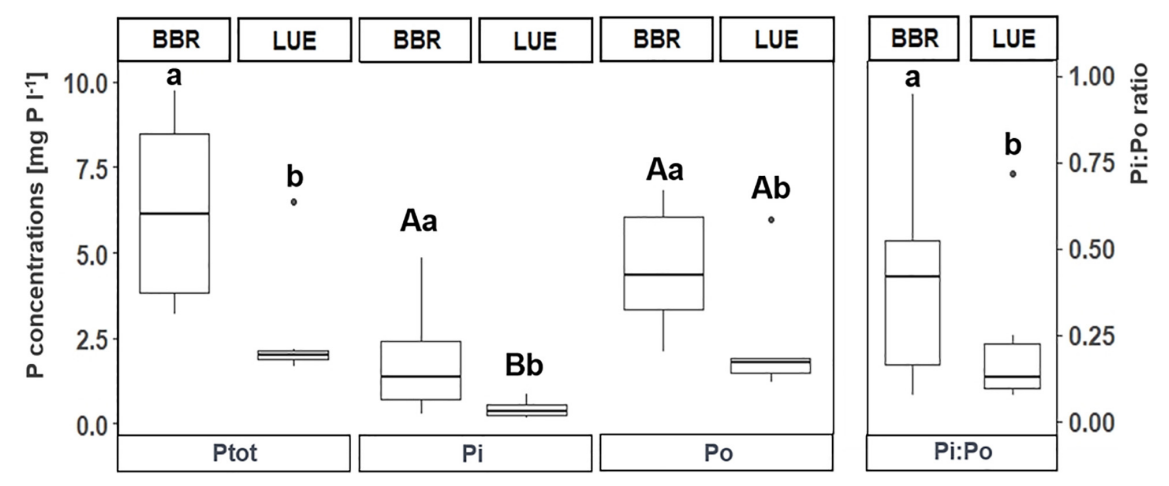

FIGURE 2 | Total (Ptot), inorganic (Pi) and organic (Po) phosphorus concentrations (mg $\mathrm{P} \mathrm{I}^{-1}$ ), and Pi:Po ratios in xylem sap of trees in the control plots. Note that $\mathrm{Pi}$ :Po ratios refer to the second $y$-axis. For ease of reading, samples were pooled from both sampling periods but treated separately for statistical analyses. Lowercase letters indicate differences between sites whereas uppercase letters indicate significant differences between Pi and Po concentrations of a given site. $\mathrm{BBR}=$ Bad Brückenau; LUE = Lüss.

AA3, XY2, Seal-Analytic, Norderstedt, Germany) at $\lambda=660 \mathrm{~nm}$, using the method of Murphy and Riley (1962). Concentration of total $\mathrm{P}$ in xylem as well as total dissolved $\mathrm{P}$ concentrations in soil extraction solutions were measured by means of Inductively Coupled Plasma/Optical Emission Spectrometry (ICP-OES, PerkinElmer Optima 5300 DVGermany) at $\lambda \mathrm{P}$ 213.617. Organic P concentrations (Po) were calculated as the difference between total $\mathrm{P}$ and $\mathrm{Pi}$ concentrations (Toor et al., 2006). Limits of detection were $0.02 \mathrm{mg} \mathrm{P}^{-1}$ for CFA and $0.05 \mathrm{mg} \mathrm{P}^{-1}$ for ICP-OES.

Soil water for $\mathrm{O}$ isotope analysis was gathered by cryoextraction (Orlowski et al., 2013). $\delta^{18} \mathrm{O}$ values of soil water extracts as well as of xylem sap were measured by cavitiy ring down spectroscopy (PICARRO Santa Clara, California, USA). The analysis of $\mathrm{O}$ isotope ratios of silver phosphate was carried out by means of a TC/EA (PYRO cube) coupled in continuous flow to an IRMS (IsoPrime100, both Elementar Analysensysteme; Hanau, Germany). Three triplicate subsamples (if enough silver phosphate was available) of each sample were weighed in silver capsules together with a small amount of glassy carbon powder to promote $\mathrm{CO}$ formation during combustion (Thermofisher scientific, Type 1, Kandel, Germany). The purity of the precipitated silver phosphate was ensured by the close match of standards and samples regarding the regression of $\mathrm{O}$ yield on analyte weight (Supplementary Figure S2). Calibration and drift-corrections were accomplished by repeated measurements of two international benzoic acid standards, IAEA 601 and IAEA $602\left(\delta^{18} \mathrm{O}=+23.3\right.$ and $+71.4 \%$, respectively; distributed by the International Atomic Energy Agency, Vienna, Austria), and one internal $\mathrm{Ag}_{3} \mathrm{PO}_{4}$ standard $\left(\delta^{18} \mathrm{O}=+10.2 \% 0\right)$. The standard deviation of triplicate measurements was $\pm 0.6 \%$.

\section{Calculations and Statistical Analyses}

General site effects were derived from a comparison of control plots between sites. In these cases, differences between sites were tested using a student's $t$-test. For single time steps and the complete design (i.e., including all treatments), we used a repeated measures ANOVA with site as between-subject factor and treatment (fertilization) as within-subject factor. Furthermore, we tested whether calculated differences between treatments $(\Delta)$ significantly deviated from zero based on a $t$-test against zero. For time series, a repeated measures ANOVA was conducted with site as between-subject factor and time step as within-subject factor. If the prerequisite for statistical analyses was violated (non-normal distribution), Wilcoxon tests were performed instead. Statistical analysis was carried out by IBM SPSS Statistics 22.

\section{RESULTS}

\section{Site Effects on P Concentrations in Xylem Sap}

Across control plots of both sites, $\mathrm{Pi}$ and $\mathrm{Po}$ concentrations ranged from 0.1 to 4.8 and 1.2 to $6.7 \mathrm{mg} \mathrm{P} \mathrm{l}^{-1}$, respectively. On average, we found $\mathrm{Pi}$ concentrations of $1.1 \pm$ standard error (SE) $0.4 \mathrm{mg} \mathrm{P}^{-1}$ and Po concentrations of $3.4 \pm \mathrm{SE} 0.6 \mathrm{mg} \mathrm{P} \mathrm{l}^{-1}$. In general, the variability of $\mathrm{P}$ concentrations in xylem was high at both sites (coefficient of variation [CV] 41\% in BBR and 63\%

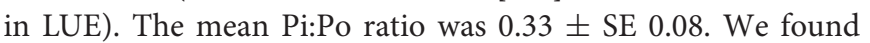
significantly higher Ptot, $\mathrm{Pi}$, and $\mathrm{Po}$ concentrations and $\mathrm{Pi}: \mathrm{Po}$ ratios in BBR than in LUE (Figure 2). In LUE, Po concentrations were 4.3 times higher than Pi concentrations (Figure 2).

\section{Site Effects on the $O$ Isotope Signature of Soil Water, Xylem Sap, and Phosphate of Xylem Sap After Application of ${ }^{18}$ O-Enriched Water}

The application of ${ }^{18} \mathrm{O}$-enriched water in the Oe horizon increased $\delta^{18} \mathrm{O}_{W}$ values of soil solution to $+41 \pm$ SE $5 \%$ across sites and sampling dates and this represented a substantial increase as compared to $\delta^{18} \mathrm{O}_{W}$ values before label application (BBR: $-8.2 \% 0 \pm$ SD 0.9\%, LUE: $-9.1 \% 0 \pm$ SD 0.5\% , Figure 3A). This increase was similarly observed in BBR and LUE (compare boxplots and dashed red line in Figure 3A). Despite the successful 

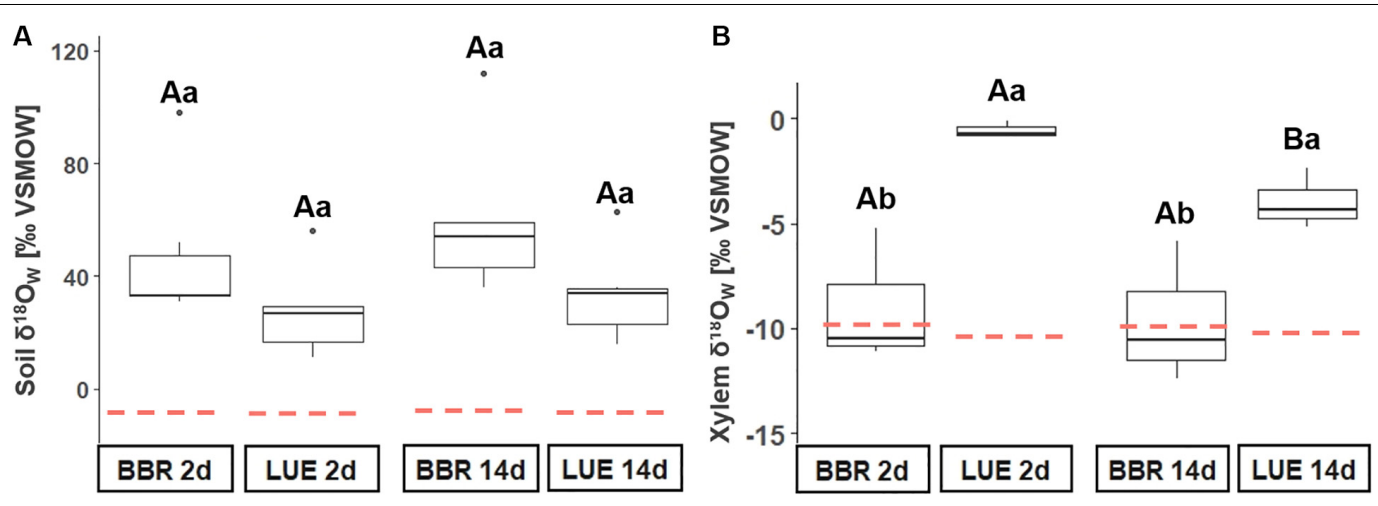

FIGURE 3 | Oxygen isotope signatures $\left(\delta^{18} \mathrm{O}\right)$ of xylem sap water $\left(x y l e m \delta^{18} \mathrm{O}_{w}\right.$, a), and soil water $\left(\right.$ soil $\left.\delta^{18} \mathrm{O}_{w}, \mathrm{~b}\right)$ of control plots on the two sampling dates $(2 \mathrm{~d}$ and $14 \mathrm{~d}=2$ days and 14 days, respectively) after addition of ${ }^{18} \mathrm{O}$-enriched water. Lowercase letters indicate significant differences between sites, whereas uppercase letters refer to significant differences between sampling dates. Red dashed lines show the background oxygen isotope signatures $\left(\delta^{18} \mathrm{O}\right)$ before ${ }^{18} \mathrm{O}$ addition (A) background: BBR: $-8.2 \% \pm$ SD 0.9\%, LUE: $-9.1 \% 0 \pm$ SD 0.5\% , (B) background: BBR: $-9.8 \%$, LUE: $-10.6 \%$; BBR $=$ Bad Brückenau; LUE $=$ Lüss.

and consistent ${ }^{18} \mathrm{O}$ labeling of soil water at both sites, $\delta^{18} \mathrm{O}_{W}$ values in xylem sap after labeling did not differ from those observed before label application in BBR (Figure 3B). By contrast, $\delta^{18} \mathrm{O}_{W}$ values of xylem sap in LUE were higher after than before labeling and significantly higher than in BBR at both sampling dates (Figure 3B). In LUE, $\delta^{18} \mathrm{O}_{W}$ values of xylem sap significantly decreased with time (Figure 3B).

At both sampling dates after the application of ${ }^{18} \mathrm{O}$-enriched water ( 2 and 14 days), $\delta^{18} \mathrm{O}_{P i}$ values of xylem sap were significantly different to the background $\delta^{18} \mathrm{O}_{P i}$ values in xylem sap (mean $\delta^{18} \mathrm{O}_{P i}$ background $=-9.15 \% 0$ in BBR and $-2.26 \%$ in LUE). In BBR, the difference significantly decreased from $26.1 \pm$ SE $1.7 \%$ to $7.8 \pm$ SE $2.4 \%$ o during the period from 2 to 14 days after label application (Figure 4). In LUE, the difference was $9.8 \pm$ SE $3.1 \%$ and $13.9 \pm$ SE $2.2 \% 2$ and 14 days after label application, respectively (Figure 4). Notably, the variation in $\delta^{18} \mathrm{O}_{P i}$ values of xylem sap was smallest 2 days after label

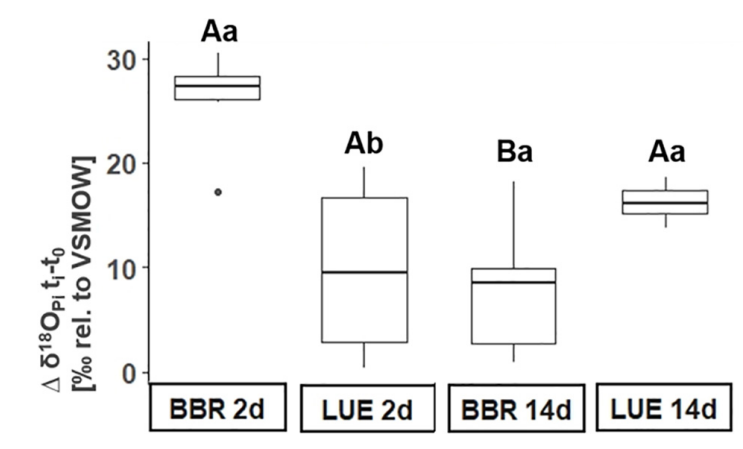

FIGURE 4 | Difference between oxygen isotope signatures of inorganic phosphate $\left(\delta^{18} \mathrm{O}_{P_{i}}\right)$ in xylem sap before (background, t0) and after addition of ${ }^{18} \mathrm{O}$-enriched water (ti) in the control plots. ti refers to the two time points after label application ( $2 \mathrm{~d}$ and $14 \mathrm{~d}=2$ days and 14 days, respectively). Lowercase letters indicate significant differences between sites, whereas uppercase letters refer to significant differences between sampling dates. $\mathrm{BBR}=$ Bad Brückenau; LUE = Lüss. application in BBR (coefficient of variation [CV] 16\% as opposed to $75 \%$ after 14 days), whereas in LUE $\delta^{18} \mathrm{O}_{P i}$ values of xylem sap varied the least 14 days after label application (CV 78 and 39\% after 2 and 14 days, respectively).

\section{Fertilizer Effects on P Concentrations and $O$ Isotope Signatures of Phosphate in Xylem Sap}

We found only few effects of fertilization on $\mathrm{P}$ concentrations in xylem sap. In BBR, $\mathrm{N}+\mathrm{P}$ addition significantly increased Ptot and $\mathrm{Pi}$ concentrations while $\mathrm{P}$ addition resulted only in increased $\mathrm{Pi}$ concentrations in xylem sap of fertilized as compared to nonfertilized trees (Figures 5A,B and Supplementary Figure S3). As a consequence, the Pi:Po ratio of xylem sap was significantly higher in the P-fertilized than the non-fertilized trees in BBR (Figure 5D). Total P concentrations in xylem sap of fertilized trees were increased as compared to non-fertilized trees by $\mathrm{P}$ addition in LUE (Figure 5, but see Supplementary Figure S3). $\delta^{18} \mathrm{O}_{P i}$ values of xylem sap were enriched in ${ }^{18} \mathrm{O}$ irrespective of fertilizer treatments in BBR two days and in LUE 14 days after labeling (Supplementary Figure S4). Strikingly, only P fertilization ( $\mathrm{P}$ and $\mathrm{NP}$ ) resulted in an ${ }^{18} \mathrm{O}$-enrichment of phosphate in xylem sap on the other sampling dates at each site (14 days in BBR and 2 days in LUE, Supplementary Figure S4). However, $\delta^{18} \mathrm{O}_{P i}$ values of xylem sap were not affected by fertilization treatments (Supplementary Figure S5).

\section{DISCUSSION}

\section{Site Effects on $\mathrm{P}$ Concentrations and $\mathrm{O}$ Isotope Signatures of Phosphate in Xylem Sap}

The ranges of 0.1 to $4.8 \mathrm{mg} \mathrm{P}^{-1}(\mathrm{Pi})$ and 1.2 to $6.7 \mathrm{mg} \mathrm{P}$ $1^{-1}(\mathrm{Po})$ in our study were in the lower range of $\mathrm{Pi}$ and $\mathrm{Po}$ concentrations of xylem sap reported in the literature (Pi: 0.5 to $70 \mathrm{mg} \mathrm{P} \mathrm{l}^{-1}$; Po: 0.5 to $80 \mathrm{mg} \mathrm{P}^{-1}$ ) (Bollard, 1960; Saur 

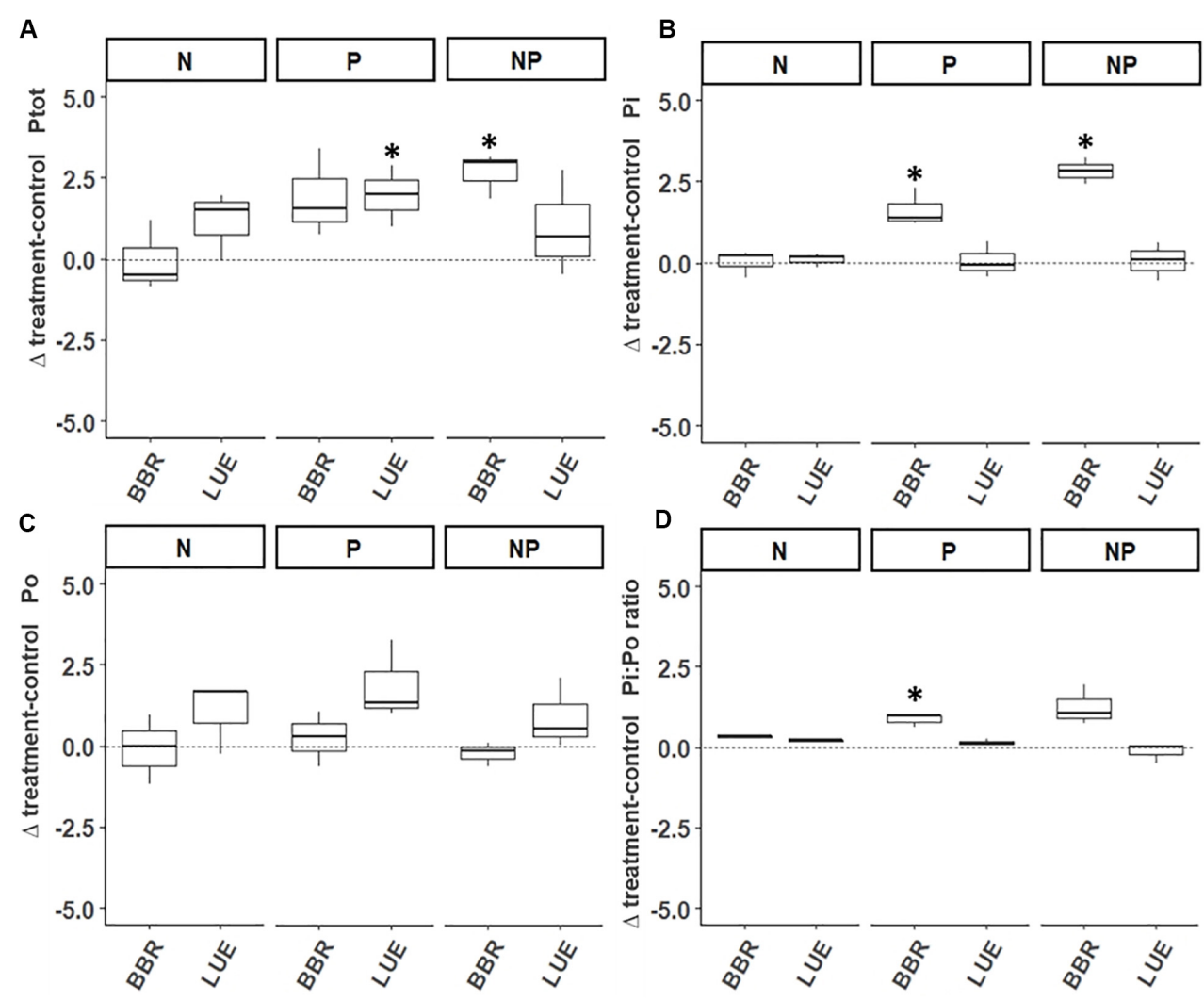

FIGURE 5 | Difference in phosphorus concentrations (mg P I-1) in xylem sap between fertilized trees (N, P, N+P) and non-fertilized trees (control) 14 days after application of 180-enriched water. Differences are displayed separately for total phosphorus (Ptot, A), inorganic phosphorus (Pi, B), organic phosphorus (Po, C) and the ratio of $\mathrm{Pi}$ to $\mathrm{Po}$ (D). Asterisks above boxplots indicate differences significantly deviating from zero (i.e., the control). BBR = Bad Brückenau; LUE = Lüss.

et al., 1995; Prima-Putra and Botton, 1998; Netzer et al., 2017). In line with our hypotheses, xylem sap total $\mathrm{P}$ concentrations were 2.3-fold higher in BBR than in LUE (Figure 2) and this was corroborated by 10 -fold higher $\mathrm{NaHCO}_{3}$-P-extractable $\mathrm{P}$ concentrations in soil in BBR as compared to LUE (Hauenstein et al., 2018). Therefore, site-specific P availability in soil was reflected in $\mathrm{P}$ concentrations of xylem sap. The significantly higher Pi:Po ratios in xylem sap at the P-rich site BBR compared to the P-poor site LUE indicates an intensified uptake of inorganic $\mathrm{P}$ from soil solution. By contrast, the low Pi:Po ratios at the P-poor site LUE could be indicative of the uptake of Po. In line, Scheerer et al. (2019) showed that small P-containing organic molecules can be taken up directly (i.e., intact) by trees. Alternatively, low Pi:Po ratios might be indicative of tree-internal P cycling. For example, Netzer et al. (2017) described higher Po concentrations in xylem at P-poor sites postulating intensified tree internal $\mathrm{P}$ remobilization and enhanced internal $\mathrm{P}$ cycling efficiency. This is further corroborated by a larger difference in $\mathrm{P}$ concentrations between leaf litter and fresh leaves and thus, higher P resorption, in LUE as compared to BBR (Lang et al., 2017). In summary, not only transformations of Po to Pi in organic layers (Hauenstein et al., 2018) but also Po uptake and tree-internal cycling are decisive for $\mathrm{P}$ nutrition of trees at the P-poor site.
Because neither site nor date influenced $\delta^{18} \mathrm{O}$ values of soil solution (Figure 3A) and because of constant temperatures as well as negligible rainfall events during the experimental course, we can exclude both the ${ }^{18} \mathrm{O}$-enrichment of soil water via evaporation (Kendall and McDonnell, 1998) and the dilution of the ${ }^{18} \mathrm{O}$ tracer in soil solution via rainfall. Despite the continuous ${ }^{18} \mathrm{O}$-enrichment of soil solution water at both sites, we observed an ${ }^{18} \mathrm{O}$-enrichment of xylem sap in LUE only (Figure 3B). Therefore, trees in LUE took up water from the organic layer to which we added the isotope label. In line, $>40 \%$ of the total fine roots (down to $1 \mathrm{~m}$ ) are located in the organic layers in LUE (Hauenstein et al., 2018) and trees rely on the organic layer for water uptake. By contrast, 9\% of the total fine roots can be found in the organic layer in BBR (Hauenstein et al., 2018) and thus, water uptake to a main proportion likely originates from deeper soil layer that we did not label. We observed differences in $\delta^{18} \mathrm{O}$ values of xylem water between sampling dates in LUE (Figure 3). These might indicate water uptake from deeper nonlabeled soil layers in LUE as well. However, the absolute difference of $3.3 \%$ is too small to pinpoint shifting patterns during the experimental course.

We found significantly increased $\delta^{18} \mathrm{O}_{P i}$ values of xylem sap at both sites (Figure 4). Notably, at both sites differences in $\delta^{18} \mathrm{O}_{P i}$ values after and before labeling were sufficiently 
large $(+15 \%)$ to exceed potential "small" isotope fractionation of ca. 3\%o associated with active transporter-driven $\mathrm{P}$ uptake (Blake et al., 2005; Gross and Angert, 2015). Furthermore, the incorporation of ${ }^{18} \mathrm{O}$ into phosphate in xylem sap might originate from tree-internal biological processes. According to textbook knowledge, neither do microorganisms colonize the protoplastfree tracheids enabling xylem sap flow nor do extracellular enzymes exist in xylem sap. Therefore, xylem-internal biological processes resulting in an incorporation of ${ }^{18} \mathrm{O}$-enriched xylem water into phosphate in xylem sap are highly unlikely. The only plausible explanation of a tree-internal ${ }^{18} \mathrm{O}$ incorporation into phosphate would be an exchange between phloem - containing P-containing metabolites produced in metabolically active plant organs such as leaves - and xylem. During metabolic reactions in leaves, $\mathrm{O}$ atoms from cell water are incorporated into phosphate (Pfahler et al., 2013). Because in our study, xylem sap water was enriched in ${ }^{18} \mathrm{O}$, this biological incorporation would be visible in xylem if there was a connection between phloem and xylem. We did not measure $\delta^{18} \mathrm{O}$ values of cell water or $\delta^{18} \mathrm{O}_{P i}$ values in leaves. However, we can roughly estimate $\delta^{18} \mathrm{O}_{P i}$ values in metabolically active $\mathrm{P}$ fractions in leaves. Leaf cell water is enriched in ${ }^{18} \mathrm{O}$ caused by preferential evaporative losses of $\mathrm{H}_{2}{ }^{16} \mathrm{O}$ (Dongmann et al., 1974). Gan et al. (2002) found a difference between xylem and leaf mesophyll water ranging from +22.1 to $+24.4 \%$ in cotton leaves. Based on $\delta^{18} \mathrm{O}$ values of xylem sap water in our study (Figure 3), $\delta^{18} \mathrm{O}$ values of leaf water of $+14 \%$ (BBR) and $+21 \%$ (LUE) would result. During metabolic reactions in leaves, all four $\mathrm{O}$ atoms in phosphate molecules are exchanged with those of cellwater- $\mathrm{O}$ and this reaction is accompanied by a temperaturedependent equilibrium fractionation (Pfahler et al., 2013) similar to observations of microbial metabolism (Blake et al., 2005). Applying the equation provided by Chang and Blake (2015) for a temperature of 13 and $8.5^{\circ} \mathrm{C}$ (mean soil temperature in $5 \mathrm{~cm}$ depth during the experiment in BBR and LUE, respectively), $\delta^{18} \mathrm{O}_{P i}$ values in leaves of $39 \%$ in BBR and $47 \%$ in LUE would result. Because estimated $\delta^{18} \mathrm{O}_{P i}$ values in leaves are far from those we observed and because we are not aware of studies on an exchange between xylem and phloem, we postulate that ${ }^{18} \mathrm{O}$ enriched phosphate in xylem sap originates from the uptake of phosphate previously biologically cycled in soil rather than from tree-internal biological cycling of $\mathrm{P}$. This assumption is in line with our finding that the biological incorporation of ${ }^{18} \mathrm{O}$ from ${ }^{18} \mathrm{O}$-enriched ambient water into phosphate was visible at both sites and was in line with the ${ }^{18} \mathrm{O}$ enrichment of soil water but not of xylem sap water.

Interestingly, for the P-rich site BBR, $\mathrm{Pi}$ and water uptake seemed to be decoupled since phosphate contained the ${ }^{18} \mathrm{O}$ label while xylem sap did not (Figures 3, 4). A decoupling of $\mathrm{P}$ and water uptake from different soil layers is plausible due to the energy-dependent active Pi uptake (Schachtman et al., 1998). Trees can adapt the active Pi uptake to changing conditions, for example to the seasonal variation in P supply (Netzer et al., 2017). Therefore, an active uptake of $\mathrm{Pi}$ is not necessarily linked to water uptake. Conversely, the location of water and P uptake seem to be identical, namely the organic layer, at the P-poor site LUE since the ${ }^{18} \mathrm{O}$ enrichment of soil water, xylem sap and phosphate in xylem sap match (Figures 3, 4). This is corroborated by the site-specific fine root distribution (Hauenstein et al., 2018) and in line with our hypotheses identifying distinct ecosystem adaptions to P-poor sites. Beside water acquisition, this might also be an adaption of trees to $\mathrm{P}$ limitation, by expanding their fine roots to locations of $\mathrm{P}$ acquisition. Nevertheless, we cannot pinpoint the exact location of water uptake due to a lack of data on $\delta^{18} \mathrm{O}_{W}$ values of deeper soil layers.

Since the $\delta^{18} \mathrm{O}_{P i}$ values of xylem sap in BBR exhibit little variability and are highly enriched in ${ }^{18} \mathrm{O}$ already 2 days after label application (Figure 4), ${ }^{18} \mathrm{O}$ from ambient water seem to be rapidly incorporated into phosphate which was subsequently taken up by trees in BBR. This short time scale is in line with the time scale of minutes to a few weeks until all four $\mathrm{O}$ atoms of a phosphate molecule are exchanged by $\mathrm{O}$ from isotopically labeled ambient water (Gross et al., 2015; von Sperber et al., 2017; Helfenstein et al., 2018). The incorporation of ${ }^{18} \mathrm{O}$ from ambient water into phosphate is mediated by enzymes such as pyrophosphatases in microorganisms (Blake et al., 2005), or mono-/diesterases (Liang and Blake, 2006; Sperber et al., 2014). The fast occurrence of the ${ }^{18} \mathrm{O}$ label in xylem sap of BBR is corroborated by higher microbial activity (Heuck and Spohn, 2016; Pistocchi et al., 2018) as well as higher phosphatase activity (Lang et al., 2017) reported for BBR as compared to LUE. At the P-poor site LUE, a distinct occurrence of the ${ }^{18} \mathrm{O}$ label occurred after 14 days (Figure 4). The slower appearance of the ${ }^{18} \mathrm{O}$ label corresponds to a slower forest floor turnover rate of 39 years in LUE compared to 5 years in BBR (Lang et al., 2017) illustrating a hampered biological activity in LUE. The slow turnover rates are linked to a greater contribution of fungi as compared to bacteria in organic matter decomposition. This is corroborated by Zavišić and Polle (2018) who highlights the importance of ectomycorrhrizal fungi (EMF) for P uptake by beech trees on P-poor sites. Similarly, Zavišić et al. (2016) pinpoint the intense colonization of root tips by EMF in the organic layers. In summary, high availability of $\mathrm{P}$ in soil is reflected in tree $\mathrm{P}$ nutrition in acquiring ecosystems such as BBR. In these ecosystems, because of high biological activity, $\mathrm{P}$ supply of trees originates from biological processes and is not necessarily linked to water supply. The source of $\mathrm{P}$ supply is similar in acquiring and recycling ecosystems, however, the retarded biological processes result in less favorable $\mathrm{P}$ nutrition of trees in recycling as compared to acquiring ecosystems.

\section{Fertilizer Effects on P Concentrations and $O$ Isotope Signatures of Phosphate in Xylem Sap}

We found that $\mathrm{P}$ addition alone and in combination with $\mathrm{N}$ increased $\mathrm{Pi}$ concentrations in xylem sap of BBR (Figure 5). Because data on tree growth or biomass are not available, it remains unclear whether the increased $\mathrm{P}$ uptake we observed for xylem sap was driven by fertilizer-induced increased biomass production or by growth-independent "luxury" P uptake. Other studies indicate that increased P uptake is mostly associated to growth-related increased P demand of trees (Goswami et al., 2018). At first sight, one might guess that the increased $P$ uptake 
derives from the fertilizer source itself. If this was the case, the $\mathrm{O}$ isotope signature of the fertilizer would predominate without shifts caused by biological cycling. However, ${ }^{18} \mathrm{O}$ enrichment of phosphate in xylem sap took place (Figure 4) and cannot be explained by fertilizer uptake because the fertilizer was not enriched in ${ }^{18} \mathrm{O}\left(\delta^{18} \mathrm{O}_{P i}\right.$ values $\left.=+19 \% 0\right)$. Furthermore, $\delta^{18} \mathrm{O}_{P i}$ values were ${ }^{18} \mathrm{O}$-enriched irrespective of treatment at the dates where the label was most intensely recovered in xylem sap at each site (BBR: 2 days, LUE: 14 days; Figure 4 and Supplementary Figure S5). At the dates where label recovery was not as pronounced (BBR: 14 days; LUE 2 days), $P$ fertilization (P, NP) still significantly increased $\delta^{18} \mathrm{O}_{P i}$ values in xylem sap which was not the case for the control and $\mathrm{N}$ treatment (Supplementary Figure S5). Because of our interpretation of the ${ }^{18} \mathrm{O}$-enrichment as a result of biological ${ }^{18} \mathrm{O}$ incorporation into phosphate prior to $\mathrm{P}$ uptake (see previous chapter on site effects), we infer that (i) fertilizer-P was cycled biologically i.e., taken up and released by soil microorganisms, and/or (ii) $\mathrm{P}$ fertilization stimulated biological activity in soil (Mo et al., 2015) and thereby increased biological incorporation of ${ }^{18} \mathrm{O}$ into phosphate prior to uptake by trees.

\section{CONCLUSION}

Our ${ }^{18} \mathrm{O}$ labeling approach highlights decoupled water and $\mathrm{P}$ uptake at the $\mathrm{P}$-rich site $\mathrm{BBR}$ representing an acquiring ecosystem. By contrast, trees relied on the organic layer for both water and P uptake at the P-poor site LUE (recycling ecosystem). Foresters should consider that ecosystem resilience particularly at P-poor ecosystems might be strongly influenced by processes that deteriorate the organic matter and subsequently changes the forest floor structure and thereby its function as a place of water retention and nutrient retention from leaching to mineral soil layers. In this regard, ongoing $\mathrm{N}$ deposition and increasing soil temperatures especially in the forest floor due to climate change have the potential to considerably change forest floor turnover dynamics. Our results further suggest that $\mathrm{N}$ deposition fosters the biological release of $\mathrm{P}$ in soil, and the subsequent uptake by trees could serve to meet the $\mathrm{N}$-induced increased $\mathrm{P}$ demand.

\section{REFERENCES}

Augusto, L., Achat, D. L., Jonard, M., Vidal, D., and Ringeval, B. (2017). Soil parent material-A major driver of plant nutrient limitations in terrestrial ecosystems. Glob. Change Biol. 23, 3808-3824. doi: 10.1111/gcb.13691

Bergkemper, F., Schöler, A., Engel, M., Lang, F., Krüger, J., Schloter, M., et al. (2016). Microbial phosphorus turnover in soil. Environ. Microbiol. 18, 1988-2000. doi: $10.1111 / 1462-2920.13188$

Blake, R. E., O'Neil, J. R., and Surkov, A. V. (2005). Biogeochemical cycling of phosphorus Insights from oxygen isotope effects of phosphoenzymes. Am. J. Sci. 305, 596-620. doi: 10.2475/ajs.305.6-8.596

Blevins, L. L., Prescott, C. E., and van Niejenhuis, A. (2006). The roles of nitrogen and phosphorus in increasing productivity of western hemlock and western redcedar plantations on northern Vancouver Island. For. Ecol. Manag. 234, 116-122. doi: 10.1016/j.foreco.2006.06.029

Bollard, E. G. (1960). Transport in the Xylem. Plant Physiol. 11, 141-166.
Therefore, in the short run $\mathrm{N}$ deposition does not necessarily induce $\mathrm{P}$ limitation.

\section{DATA AVAILABILITY STATEMENT}

The datasets generated for this study are available on request to the corresponding author.

\section{AUTHOR CONTRIBUTIONS}

YO conceived the idea of the study. $\mathrm{SH}$ and $\mathrm{MN}$ conducted the study. SH and YO was jointly wrote the manuscript. All authors contributed to the article and approved the submitted version.

\section{FUNDING}

The authors gratefully acknowledge funding by the German Research Foundation (DFG) (Oe516/6-2 in the priority program 1685).

\section{ACKNOWLEDGMENTS}

This project was carried out in the framework of the priority programme 1685 "Ecosystem Nutrition: Forest Strategies for limited Phosphorus Resources". We are grateful for support by the forest tree climbers from Michael Furche Baumservice and Baumfällung de Vries. We want to thank the SPP coordinators (Prof. Dr. Friederike Lang and Dr. Jaane KrÃijger, University of Freiburg, Germany) for their support. Furthermore, we thank all people involved in establishing and maintaing the monitoring sites as well as the fertilization experiment.

\section{SUPPLEMENTARY MATERIAL}

The Supplementary Material for this article can be found online at: https://www.frontiersin.org/articles/10.3389/ffgc.2020. 542738/full\#supplementary-material

Chang, S. J., and Blake, R. E. (2015). Precise calibration of equilibrium oxygen isotope fractionations between dissolved phosphate and water from 3 to $37^{\circ}$ C. Geochimica Cosmochimica Acta 150, 314-329. doi: 10.1016/j.gca.2014. 10.030

Clarholm, M. (1993). Microbial biomass P, labile P, and acid phosphatase activity in the humus layer of a spruce forest, after repeated additions of fertilizers. Biol. Fert. Soils 16, 287-292. doi: 10.1007/bf00369306

DeForest, J. L., Smemo, K. A., Burke, D. J., Elliott, H. L., and Becker, J. C. (2012). Soil microbial responses to elevated phosphorus and $\mathrm{pH}$ in acidic temperate deciduous forests. Biogeochemistry 109, 189-202. doi: 10.1007/s10533-0119619-6

Dongmann, G., Nrnberg, H. W., Frstel, H., and Wagener, K. (1974). On the enrichment of $\mathrm{H} 218 \mathrm{O}$ in the leaves of transpiring plants. Radiat. Environ. Biophys. 11, 41-52. doi: 10.1007/BF01323099

Finzi, A. C. (2009). Decades of atmospheric deposition have not resulted in widespread phosphorus limitation or saturation of tree demand for nitrogen 
in southern New England. Biogeochemistry 92, 217-229. doi: 10.1007/s10533009-9286-Z

Gan, K. S., Wong, S. C., Yong, J. W. H., and Farquhar, G. D. (2002). 18 O spatial patterns of vein xylem water, leaf water, and dry matter in cotton leaves. Plant Physiol. 130, 1008-1021. doi: 10.1104/pp.007419

Gaudio, N., Belyazid, S., Gendre, X., Mansat, A., Nicolas, M., Rizzetto, S., et al. (2015). Combined effect of atmospheric nitrogen deposition and climate change on temperate forest soil biogeochemistry: a modeling approach. Ecol. Model. 306, 24-34. doi: 10.1016/j.ecolmodel.2014.10.002

Goswami, S., Fisk, M. C., Vadeboncoeur, M. A., Garrison-Johnston, M., Yanai, R. D., and Fahey, T. J. (2018). Phosphorus limitation of aboveground production in northern hardwood forests. Ecology 99, 438-449. doi: 10.1002/ ecy. 2100

Gross, A., and Angert, A. (2015). What processes control the oxygen isotopes of soil bio-available phosphate? Geochim. Cosmochim. Acta 159, 100-111. doi: 10.1016/j.gca.2015.03.023

Gross, A., Turner, B. L., Wright, S. J., Tanner, E. F. J., Reichstein, M., Weiner, T., et al. (2015). Oxygen isotope ratios of plant available phosphate in lowland tropical forest soils. Soil Biol. Biochem. 88, 354-361. doi: 10.1016/j.soilbio.2015. 06.015

Hacker, N., Wilcke, W., and Oelmann, Y. (2019). The oxygen isotope composition of bioavailable phosphate in soil reflects the oxygen isotope composition in soil water driven by plant diversity effects on evaporation. Geochim. Cosmochim. Acta 248, 387-399. doi: 10.1016/j.gca.2018.11.023

Hansson, K., Laclau, J.-P., Saint-André, L., Mareschal, L., van der Heijden, G., Nys, C., et al. (2020). Chemical fertility of forest ecosystems. Part 1: common soil chemical analyses were poor predictors of stand productivity across a wide range of acidic forest soils. For. Ecol. Manag. 461:117843. doi: 10.1016/j.foreco. 2019.117843

Hauenstein, S., Neidhardt, H., Lang, F., Krüger, J., Hofmann, D., Pütz, T., et al. (2018). Organic layers favor phosphorus storage and uptake by young beech trees (Fagus sylvatica L.) at nutrient poor ecosystems. Plant Soil 432, 289-301. doi: 10.1007/s11104-018-3804-5

Haußmann, T., and Lux, W. (1997). Dauerbeobachtungsflächen zur Umweltkontrolle im Wald: Level II ; Erste Ergebnisse. BMELF (Bundesministerium für Ernährung, Landwirtschaft und Forsten). Bonn, Germany.

Helfenstein, J., Tamburini, F., Sperber, C. V., Massey, M. S., Pistocchi, C., Chadwick, O. A., et al. (2018). Combining spectroscopic and isotopic techniques gives a dynamic view of phosphorus cycling in soil. Nat. Commun. 9:3226. doi: 10.1038/s41467-018-05731-2

Heuck, C., and Spohn, M. (2016). Carbon, nitrogen and phosphorus net mineralization in organic horizons of temperate forests: stoichiometry and relations to organic matter quality. Biogeochemistry 131, 229-242. doi: 10.1007/ s10533-016-0276-7

IUSS WG WRB. (2015). "World reference base for soil resources 2014, update 2015," in International Soil Classification System for Naming Soils and Creating Legends for Soil Maps. World Soil Resources Reports No. 106. (Rome: FAO), 153-154.

Janssens, I. A., Dieleman, W., Luyssaert, S., Subke, J.-A., Reichstein, M., Ceulemans, R., et al. (2010). Reduction of forest soil respiration in response to nitrogen deposition. Nat. Geosci. 3, 315-322. doi: 10.1038/ngeo844

Jonard, M., Furst, A., Verstraeten, A., Thimonier, A., Timmermann, V., Potocic, N., et al. (2015). Tree mineral nutrition is deteriorating in Europe. Glob. Change Biol. 21, 418-430. doi: 10.1111/gcb.12657

Jonard, M., Legout, A., Nicolas, M., Dambrine, E., Nys, C., Ulrich, E., et al. (2012). Deterioration of Norway spruce vitality despite a sharp decline in acid deposition: a long-term integrated perspective. Glob. Change Biol. 18, 711-725. doi: 10.1111/j.1365-2486.2011.02550.x

Kendall, C., and McDonnell, J. J. (1998). Isotope Tracers in Catchment Hydrology. Amsterdam: Elsevier.

Lang, F., Bauhus, J., Frossard, E., George, E., Kaiser, K., Kaupenjohann, M., et al. (2016). Phosphorus in forest ecosystems: new insights from an ecosystem nutrition perspective. J. Plant Nutr. Soil Sci. 179, 129-135. doi: 10.1002/jpln. 201500541

Lang, F., Krüger, J., Amelung, W., Willbold, S., Frossard, E., Bünemann, E. K., et al. (2017). Soil phosphorus supply controls P nutrition strategies of beech forest ecosystems in Central Europe. Biogeochemistry 127:255. doi: 10.1007/s10533017-0375-0

Legout, A., Hansson, K., van der Heijden, G., Laclau, J.-P., Mareschal, L., Nys, C., et al. (2020). Chemical fertility of forest ecosystems. Part 2: towards redefining the concept by untangling the role of the different components of biogeochemical cycling. For. Ecol. Manag. 461:117844. doi: 10.1016/j.foreco. 2019.117844

Liang, Y., and Blake, R. E. (2006). Oxygen isotope signature of Pi regeneration from organic compounds by phosphomonoesterases and photooxidation. Geochim. Cosmochim. Acta 70, 3957-3969. doi: 10.1016/j.gca.2006. 04.036

Liang, Y., and Blake, R. E. (2007). Oxygen isotope fractionation between apatite and aqueous-phase phosphate: $20-45^{\circ} \mathrm{C}$. Chem. Geol. 238, 121-133. doi: 10. 1016/j.chemgeo.2006.11.004

Lorenz, M. (1995). International Co-operative programme on assessment and monitoring of air pollution effects on forests-ICP forests-. Water Air Soil Pollut. 85, 1221-1226. doi: 10.1007/BF00477148

Lovett, G. M., Arthur, M. A., Weathers, K. C., Fitzhugh, R. D., and Templer, P. H. (2013). Nitrogen addition increases carbon storage in soils, but not in trees, in an Eastern U.S. deciduous forest. Ecosystems 16, 980-1001. doi: 10.1007/ s10021-013-9662-3

Magill, A. H., Aber, J. D., Currie, W. S., Nadelhoffer, K. J., Martin, M. E., McDowell, W. H., et al. (2004). Ecosystem response to 15 years of chronic nitrogen additions at the Harvard Forest LTER, Massachusetts, USA. For. Ecol. Manag. 196, 7-28. doi: 10.1016/j.foreco.2004.03.033

Marklein, A. R., and Houlton, B. Z. (2012). Nitrogen inputs accelerate phosphorus cycling rates across a wide variety of terrestrial ecosystems. New Phytol. 193, 696-704. doi: 10.1111/j.1469-8137.2011.03967.x

Marschner, H. (ed.). (2002). "Introduction, definition, and classification of mineral nutrients," in Marschner's Mineral Nutrition of Higher Plants, 2 Edn. (Academic Press), 3-5. doi: 10.1016/B978-0-08-057187-4.50007-2

Mo, Q., Zou, B., Li, Y., Chen, Y., Zhang, W., Mao, R., et al. (2015). Response of plant nutrient stoichiometry to fertilization varied with plant tissues in a tropical forest. Sci. Rep. 5:14605. doi: 10.1038/srep14605

Murphy, J., and Riley, J. P. (1962). A modified single solution method for the determination of phosphate in natural waters. Anal. Chim. Acta 27, 31-36. doi: 10.1016/S0003-2670(00)88444-5

Nadelhoffer, K. J., Colman, B. P., Currie, W. S., Magill, A., and Aber, J. D. (2004). Decadal-scale fates of tracers added to oak and pine stands under ambient and elevated $\mathrm{N}$ inputs at the Harvard Forest (USA). For. Ecol. Manag. 196, 89-107. doi: 10.1016/j.foreco.2004.03.014

Nave, L. E., Vance, E. D., Swanston, C. W., and Curtis, P. S. (2009). Impacts of elevated $\mathrm{N}$ inputs on north temperate forest soil $\mathrm{C}$ storage, $\mathrm{C} / \mathrm{N}$, and net N-mineralization. Geoderma 153, 231-240. doi: 10.1016/j.geoderma.2009.08. 012

Netzer, F., Schmid, C., Herschbach, C., and Rennenberg, H. (2017). Phosphorusnutrition of European beech (Fagus sylvatica L.) during annual growth depends on tree age and P-availability in the soil. Environ. Exp. Bot. 137, 194-207. doi: 10.1016/j.envexpbot.2017.02.009

Odum, E. P. (2014). “The strategy of ecosystem development," in The Ecological Design and Planning Reader, ed. F. O. Ndubisi (Washington, DC: Island Press/Center for Resource Economics), 203-216. doi: 10.5822/978-1-61091491-8_20

Orlowski, N., Frede, H.-G., Brüggemann, N., and Breuer, L. (2013). Validation and application of a cryogenic vacuum extraction system for soil and plant water extraction for isotope analysis. J. Sens. Sens. Syst. 2, 179-193. doi: 10.5194/jsss2-179-2013

Peñuelas, J., Poulter, B., Sardans, J., Ciais, P., van der Velde, M., Bopp, L., et al. (2013). Human-induced nitrogen-phosphorus imbalances alter natural and managed ecosystems across the globe. Nat. Commun. 4:2934. doi: 10.1038/ ncomms3934

Peñuelas, J., and Sardans, J. (2012). The role of plants in the effects of global change on nutrient availability and stoichiometry in the plant-soil system. Plant Physiol. 160, 1741-1761. doi: 10.1104/pp.112.208785

Pfahler, V., Dürr-Auster, T., Tamburini, F., Bernasconi, M. S., and Frossard, E. (2013). 18 O enrichment in phosphorus pools extracted from soybean leaves. New Phytol. 197, 186-193. doi: 10.1111/j.1469-8137.2012.04379.x 
Pistocchi, C., Mészáros, É, Tamburini, F., Frossard, E., and Bünemann, E. K. (2018). Biological processes dominate phosphorus dynamics under low phosphorus availability in organic horizons of temperate forest soils. Soil Biol. Biochem. 126, 64-75. doi: 10.1016/j.soilbio.2018.08.013

Polglase, P. J., Jokela, E. J., and Comerford, N. B. (1992). Phosphorus, nitrogen, and carbon fractions in litter and soil of Southern pine plantations. Soil Sci. Soc. Am. J. 56, 566-573. doi: 10.2136/sssaj1992.03615995005600020036x

Porder, S., and Ramachandran, S. (2012). The phosphorus concentration of common rocks-a potential driver of ecosystem P status. Plant Soil 367, 41-55. doi: 10.1007/s11104-012-1490-2

Pregitzer, K. S., Burton, A. J., Zak, D. R., and Talhelm, A. F. (2007). Simulated chronic nitrogen deposition increases carbon storage in Northern Temperate forests. Glob. Change Biol. 14, 142-153. doi: 10.1111/j.1365-2486.2007.01465.x

Prietzel, J., and Stetter, U. (2010). Long-term trends of phosphorus nutrition and topsoil phosphorus stocks in unfertilized and fertilized Scots pine (Pinus sylvestris) stands at two sites in Southern Germany. For. Ecol. Manag. 259, 1141-1150. doi: 10.1016/j.foreco.2009.12.030

Prima-Putra, D., and Botton, B. (1998). Organic and inorganic compounds of xylem exudates from five woody plants at the stage of bud breaking. J. Plant Physiol. 153, 670-676. doi: 10.1016/S0176-1617(98)80219-8

Saur, E., Brechet, C., Lambrot, C., and Masson, P. (1995). Micronutrient composition of xylem sap and needles as a result of P-fertilization in maritime pine. Trees 10, 52-54. doi: 10.1007/BF00197780

Schachtman, D. P., Reid, R. J., and Ayling, S. M. (1998). Phosphorus uptake by plants: from soil to cell. Plant Physiol. 116, 447-453. doi: 10.1104/pp.116.2.447

Scheerer, U., Netzer, F., Bauer, A. F., and Herschbach, C. (2018). Measurements of $18 \mathrm{O}-\mathrm{Pi}$ uptake indicate fast metabolism of phosphate in tree roots. Plant Biol. 21, 565-570. doi: 10.1111/plb.12922

Scheerer, U., Trube, N., Netzer, F., Rennenberg, H., and Herschbach, C. (2019). ATP as phosphorus and nitrogen source for nutrient uptake by Fagus sylvatica and Populus x Canescens roots. Front. Plant Sci. 10:378. doi: 10.3389/fpls.2019. 00378

Shaw, A. N., and DeForest, J. L. (2013). The cycling of readily available phosphorus in response to elevated phosphate in acidic temperate deciduous forests. Appl. Soil Ecol. 63, 88-93. doi: 10.1016/j.apsoil.2012.09.008

Sperber, C. V., Kries, H., Tamburini, F., Bernasconi, S. M., and Frossard, E. (2014). The effect of phosphomonoesterases on the oxygen isotope composition of phosphate. Geochim. Cosmochim. Acta 125, 519-527. doi: 10.1016/j.gca.2013. 10.010

Talkner, U., Meiwes, K. J., Potoèiæ, N., Seletkoviæ, I., Cools, N., Vos, B. D., et al. (2015). Phosphorus nutrition of beech (Fagus sylvatica L.) is decreasing in Europe. Ann. For. Sci. 72, 919-928. doi: 10.1007/s13595-015-0459-8
Toor, G. S., Hunger, S., Derek Peak, J., Thomas Sims, J., and Sparks, D. L. (2006). Advances in the characterization of phosphorus in organic wastes: environmental and agronomic applications. Acta Sci. Agron. 89, 1-72. doi: 10.1016/S0065-2113(05)89001-7

Trichet, P., Bakker, M. R., Augusto, L., Alazard, P., Merzeau, D., and Saur, E. (2009). Fifty Years of fertilization experiments on pinus pinaster in Southwest france: the importance of phosphorus as a fertilizer. For. Sci. 55, 390-402.

Turner, J., and Lambert, M. J. (2015). Long-term growth responses to phosphatic fertilisers in a Pinus radiata plantation. Austral. For. 78, 207-218. doi: 10.1080/ 00049158.2015.1071679

von Sperber, C., Lewandowski, H., Tamburini, F., Bernasconi, S. M., Amelung, W., and Frossard, E. (2017). Kinetics of enzyme-Řcatalysed oxygen isotope exchange between phosphate and water revealed by Raman spectroscopy. J. Raman Spectrosc. 48, 368-373. doi: 10.1002/jrs.5053

Waldrop, M. P., and Firestone, M. K. (2004). Altered utilization patterns of young and old soil $\mathrm{C}$ by microorganisms caused by temperature shifts and $\mathrm{N}$ additions. Biogeochemistry 67, 235-248. doi: 10.1023/B:BIOG.0000015321.514 62.41

Weiner, T., Mazeh, S., Tamburini, F., Frossard, E., Bernasconi, S. M., Chiti, T., et al. (2011). A method for analyzing the $\delta 180$ of resin-extractable soil inorganic phosphate. Rapid Commun. Mass Spectrom. 25, 624-628. doi: 10.1002/rcm. 4899

Zavišić, A., and Polle, A. (2018). Dynamics of phosphorus nutrition, allocation and growth of young beech (Fagus sylvatica L.) trees in P-rich and P-poor forest soil. Tree Physiol. 38, 37-51. doi: 10.1093/treephys/ tpx146

Zavišić, A., Nassal, P., Yang, N., Heuck, C., Spohn, M., Marhan, S., et al. (2016). Phosphorus availabilities in beech (Fagus sylvatica L.) forests impose habitat filtering on ectomycorrhizal communities and impact tree nutrition. Soil Biol. Biochem. 98, 127-137. doi: 10.1016/j.soilbio.2016. 04.006

Conflict of Interest: The authors declare that the research was conducted in the absence of any commercial or financial relationships that could be construed as a potential conflict of interest.

Copyright (C) 2020 Hauenstein, Nebel and Oelmann. This is an open-access article distributed under the terms of the Creative Commons Attribution License (CC BY). The use, distribution or reproduction in other forums is permitted, provided the original author(s) and the copyright owner(s) are credited and that the original publication in this journal is cited, in accordance with accepted academic practice. No use, distribution or reproduction is permitted which does not comply with these terms. 